\title{
Imperial Mycology.
}

$\mathrm{T}^{\mathrm{T}}$ HE second Imperial Mycological Conference was recently held under the auspices of the Imperial Bureau of Mycology, the first having taken place immediately before the Imperial Botanical Conference in 1924, when it was resolved that a Conference should be held every five years. The Imperial Bureau of Mycology has as its work the assisting of overseas phytopathologists and the publication of an abstracting journal of applied mycology.

A Conference such as the one just held is advantageous for many reasons, most of which areobvious when one considers the comparative isolation of several of the workers in this vast subject. Moreover, the necessity for appointing plant pathologists or mycologists was recognised only comparatively recently in many parts of the Empire, with the result that several of the men who hold such posts have obtained their training and experience since the War. With great responsibilities, it is to their advantage to meet men similarly engaged, whether the crops with which they have to deal are the same or not. Planters as a class are interested merely in the successful growing of crops, and no matter what the crop or which the region, the chief interest of the phytopathologist as such is the same. Consequently, it was a wise move to issue a somewhat general invitation to home workers to contribute to the discussions.

A further point is that these conferences enable a degree of co-ordination of policies, and a taking stock of the present position of research in several matters of outstanding importance. Thus there was a discussion on virus diseases, which are so prominent in all pathology, one on the root diseases of orchard and permanent crops, one on the epidemiology of some cereal diseases, and one on fruit storage rots. Furthermore, the opportunity was taken to define the lines on which meteorological records and forecasts could best be utilised in the more exact timing of preventive spraying against crop diseases. Some of these matters would have been discussed whether or not they had a place in the formal programme, and the time given to them probably marked out the scope for extra-mural talks.

The resolutions which were passed at the close of the Conference give a summary of the main trend of the proceedings, and show the large part played by matters directly and indirectly concerned with plant protection. To aid in a discussion on the existing organisation of plant pathological (plant protection) services in various parts of the Empire, a list was compiled giving the branch of government service under which plant protection is placed, the members of the scientific staff, the inspectorate and co-operative personnel and 'projects under way'. The increase in the numbers of plant pathologists in some countries (for example, Canada) during the past few years is striking, and doubtless explains to some extent the claims of British universities that there is a great demand for biologists overseas ; a friendly rivalry to create the most efficient research and administrative service may keep the demand steady for some time, but the proportion of workers trained overseas is steadily increasing.

A change comparable with that in the number of plant pathologists is seen in the plant protection regulations of the dominions and colonies. Much has been made of the political and economic aspects of certain recent regulations which have as their avowed object the prevention of the introduction of disease, but the experience of the United States with chestnut blight and pine blister rust, to take two well-known examples, are sufficient warrant for measures analogous to those for dealing with plague, cholera, or small-pox. The chances of introducing a 'new' disease into a country are nowadays almost incalculable, and when air traffic attains the dimensions prophesied for it we shall have to take other factors into account, for plant disease is more easily disseminated than human disease.

There is considerable diversity in the regulations of the different overseas areas, and it would doubtless ensure that they were more efficiently carried out if there was some standardisation. Obviously, there are difficulties in co-ordinating legislation for widely separated areas, but differences between that of say Kenya, Tanganyika, Uganda, and Zanzibar seem unnecessary. The Conference recommended that countries between which planting material frequently passes should endeavour to group themselves together to investigate the possibility of finding a minimum treatment for any specific pest or disease of a particular plant of which the export is desired.

Most of the dominions and colonies have taken measures to exclude specific plants either com. pletely or from certain countries; sometimes all plants from certain places are excluded. Frequently, specified plants are allowed entrance subject to licence from the local authority, the conditions of the permit not usually being published though sometimes obtainable by intending importers. This is carried so far in Tanganyika that no living plant may be imported except under permit. Where well-known diseases are in question, official certificates are often required, usually to the effect that the disease is not known either in the country or in the district of origin ; or only varieties proved to be immune are allowed entry. Many governments require the specified plants to be grown for some time in quarantine, and the Conference was of opinion that such provision should be included in all plant protection legislation. Most governments provide for the compulsory examination of all plant imports and the destruction or treating of plant packings.

Such regulations refer to the importing of plants, and countries wishing to export have to take them into account. But, as in human disease, the health service of the country itself is of chief concern, and import regulations are only an attempt to prevent the spread of disease to crops grown 
within a given area. The measures for what is sometimes called 'internal plant protection' need not be co-ordinated between the different overseas countries; what is needed is that the most efficient methods for ensuring healthy crops be adopted, and this is a matter for each individual government. Usually, inspectors are appointed with powers to inspect crops and to prescribe specific treatment. The authority to destroy diseased plants may rest with the inspector but ranges up to a Minister; and similarly with powers of quarantine which may involve whole districts. Usually, compensation is payable at the discretion of the government, but this may be restricted to the destruction of healthy plants. Further, a grower may be compelled to destroy all dead plants of a crop, or may be forbidden to allow cultivated land to run wild unless the crop is destroyed.

A somewhat different aspect of the matter is seen in South Africa, where the majority of growers in an orchard area may request that the provisions of the Orchard Cleansing Act be applied to that area-and in Kenya, where a coffee plant may not be moved to another estate except under permit from the Director of Agriculture.

That special attention should be given to nurseries is obvious. It is usual for registered nurseries only to be allowed to offer plants for sale under an annual certificate of inspection and freedom from disease.

Most countries issue certificates of health for exports where needed, and occasionally no export is allowed without such a certificate. The Conference was of opinion that the system of certificates should be universally recognised, and drew up a form of certificate for approval and adoption.

Plant protection is given a more familiar bias in South Africa, where it is the declared policy to permit only imports of varieties or species that cannot be procured locally in adequate quantity and quality. Permission to import plants or cuttings is not given if seed will do. Here we have a similar regulation to the one which caused considerable uproar when passed by the United States a few years ago, and has meant so much 'dumping' of Dutch bulbs into Great Britain. The reference to seeds is interesting; for seeds seldom appear to be subject to import regulation. It is becoming recognised that seed-borne diseases are more important than was previously considered, and as the result of a discussion, the Conference suggested that the subject should be given increased attention throughout the Empire.

The need for a series of handbooks on the diseases of tropical and subtropical crops is much felt by those who are concerned mainly with two or three of these crops, for information is scattered over many periodicals. A subcommittee which was appointed to consider this drew up a list of eleven subjects and a provisional scheme of treatment, but it emphasised that " the series must be of outstanding merit, otherwise it would be preferable to drop the scheme altogether ".

The difficulties met with in tracing accounts of the diseases of a given crop are as nothing when compared with that of finding a way through the tangle of the literature of mycological taxonomy, and it is well worth noting that, in a Conference where the so-called practical side of mycology was rightly predominant, the first resolution passed concerned systematy. It was decided to refer to the International Botanical Congress the necessity for an abstracting journal of the world's literature on mycological taxonomy. This indicates a more general interest in pure mycology than has been apparent during recent years, and one which, if it is developed in the spirit of those men who have done most for phytopathology both at home and in the overseas Empire, will surely bring forth abounding results.

\section{Search for an Oil-Pool in Kent.}

\section{By Henry B. Milner.}

$\mathrm{O}^{\mathrm{s}}$ NE would have imagined that the history of oil exploration in the British Isles was sufficiently common knowledge to shake the faith of the most ardent believer in undiscovered resources, but apparently not. The attack on subWealden hydrocarbons has broken out afresh, this time in Kent, and the possibilities of great finds of oil are optimistically envisaged. We are informed that permission has been granted by the War Office for a well to be put down on land given over to the rifle ranges near Hythe, and that the operators responsible for the project anticipate a 'strike' at about $1000 \mathrm{ft}$.

It would be interesting to learn the technical grounds (if any) on which hopes of such a discovery are based. That competent geological opinion has been sought, or that this proposed venture is the result of closely reasoned evidence, it is difficult to believe. We thought that the myth of enormous natural gas reserves, of which
Heathfield, Sussex, was once considered to be an active indication, had been exploded long ago, so far as the Weald was concerned; maybe this present project has been conceived quite independently of any regard for what the concealed rocks of Sussex may or may not hold, though we can scarcely credit even elementary geological conceptions with disinclination to associate the two possibilities.

The geological column beneath Hythe cannot fail to be a most interesting and scientifically im. portant link in the chain of evidence of the preCretaceous rocks of the coastal margin of the Weald; to this extent a deep boring, carefully logged and sampled, is a most welcome happening. Presumably the operators in question have some idea of the rock succession they propose to traverse, and one is led at once to speculate on what data they rely for their forecast, not only of the occurrence of petroleum, but also of the rocks with which

No. 3132, VoL. 124] 